\title{
Pollen of plane in the air of selected cities of Poland in 2018
}

\author{
Barbara Gałusza', Agnieszka Lipiec², Małgorzata Puc ${ }^{3,4}$, Alina Stacewicz ${ }^{3,4}$, Zenon Siergiejko5, \\ Adam Rapiejko ${ }^{6,7}$, Krystian Tywoniuk ${ }^{8}$, Kornel Szczygielski', Dariusz Jurkiewicz', Grzegorz Siergiejko ${ }^{9}$, \\ Ewa M. Świebocka ${ }^{9}$, Piotr Rapiejko ${ }^{1,5}$ \\ ${ }^{1}$ Department of Otolaryngology with Division of Cranio-Maxillo-Facial Surgery in Military Institute of Medicine, \\ Warsaw, Poland \\ ${ }^{2}$ Department of Prevention of Environmental Hazards and Allergology, Medical University of Warsaw, Poland \\ ${ }^{3}$ Department of Botany and Nature Conservation, Faculty of Biology, University of Szczecin, Poland \\ ${ }^{4}$ Molecular Biology and Biotechnology Centre, Faculty of Biology, University of Szczecin, Poland \\ ${ }^{5}$ Laboratory of Respiratory Diagnostics and Bronchoscopy, Medical University of Bialystok, Poland \\ ${ }^{6}$ Allergen Research Center, Poland \\ ${ }^{7}$ Oxford Archaeology Ltd., Oxford, England \\ ${ }^{8}$ Department of Otolaryngology, Audiology and Phoniatrics, Children's Hospital of Bydgoszcz, Poland \\ ${ }^{9}$ The Medical University of Bialystok Children's Clinical Hospital, Poland
}

\section{Abstract:}

The course of plane pollen season in Bialystok, Bydgoszcz, Drawsko Pomorskie, Olsztyn, Opole, Szczecin, Warsaw and in Zielona Gora in the year 2018 was presented. Measurements were performed by the volumetric method (Lanzoni or Burkard pollen sampler). Pollen season was defined as the period in which $98 \%$ of the annual total catch occurred. In most of the cities, the plane pollen season in 2018 started in the second decade of April. The highest airborne concentration of 87 pollen grains $/ \mathrm{m}^{3}$ was noted in Zielona Gora on the April $28^{\text {th }}$ and in Opole ( 85 pollen grains $/ \mathrm{m}^{3}$ ) on the April $29^{\text {th }}$. The high pollen count of plane has a local character resulting from the number of trees in cities. The highest risk of pollen allergy associated with the presence of airborne plane pollen was found in Zielona Gora, Opole, Warsaw and Szczecin.

Key words: pollen count, plane tree, allergens, 2018

$\mathrm{n}$ Poland, plane tree pollen allergens are rarely the cause of allergic diseases, while in the eastern part of the Mediterranean area they show high allergenicity. In Europe, plane trees are often planted in cities because they tolerate air pollution well; many are filled in parks as well as along streets and alleys $[1,2]$.

Aim

The aim of the study was to compare the plane tree pollen concentrations in the air of Bialystok, Byd- goszcz, Drawsko Pomorskie, Olsztyn, Opole, Szczecin, Warsaw, Zielona Gora in 2018.

\section{Material and method}

The measurements of the pollen concentration in the study sites were performed with the volumetric method using Lanzoni and Burkard pollen samplers. Microscopic observations were performed on preparations obtained in a 7-day cycle with assessment of 24-hour periods [3]. The results were expressed as the 
number of pollen grains in $1 \mathrm{~m}^{3}$ of air per day $\left(\mathrm{P} / \mathrm{m}^{3}\right)$ [3]. The total pollen count over this period was expressed by the symbol SPI (Seasonal Pollen Index).

\section{Results and discussion}

The first pollen grains were observed in the air of Szczecin and Zielona Gora on April 10 ${ }^{\text {th }}$, and the last ones in Opole on May 19 $9^{\text {th }}$ The course of the pollen seasons in each city is shown in the graphs (figs 1-4).

The highest airborne concentration of 87 pollen grains $/ \mathrm{m}^{3}$ was noted in Zielona Gora on April $28^{\text {th }}$, in Opole ( 85 pollen grains $/ \mathrm{m}^{3}$ ) on April $29^{\text {th }}$, in Szczecin $\left(61\right.$ grains $\left./ \mathrm{m}^{3}\right)$ on May $3^{\text {rd }}$ and in Warsaw (43 grains $/ \mathrm{m}^{3}$ ) on May $3^{\text {rd }}$.

Table 1. Characteristics of plane tree pollen season in 2018.

\begin{tabular}{|c|c|c|c|c|}
\hline Site & $\begin{array}{l}\text { Duration of pollen } \\
\text { season (days) }\end{array}$ & $\begin{array}{c}\text { Peak value }\left[\mathrm{P} / \mathrm{m}^{3}\right] \text { and } \\
\text { peak date }\end{array}$ & Annual pollen sum (SPI) & $\begin{array}{l}\text { Number of days concentration } \\
\text { above threshold } 15 \mathrm{P} / \mathrm{m}^{3}\end{array}$ \\
\hline Bialystok & 16.05.-15.05 & $4(15.05)$ & 27 & 0 \\
\hline Bydgoszcz & $14.04-10.05$ & $21(4.05)$ & 186 & 3 \\
\hline Drawsko Pomorskie & $19.04-10.05$ & $8(7.06)$ & 57 & 0 \\
\hline Olsztyn & $19.04-12.05$ & $12(1.05)$ & 46 & 0 \\
\hline Opole & $17.04-12.05$ & $85(29.04)$ & 693 & 15 \\
\hline Szczecin & $10.04-12.05$ & $61(3.05)$ & 263 & 6 \\
\hline Warsaw & $23.04-13.05$ & $43(3.05)$ & 285 & 7 \\
\hline Zielona Gora & $13.04-8.05$ & $87(28.04)$ & 753 & 16 \\
\hline
\end{tabular}

Figure 1. Plane pollen count in Bialystok and Bydgoszcz.

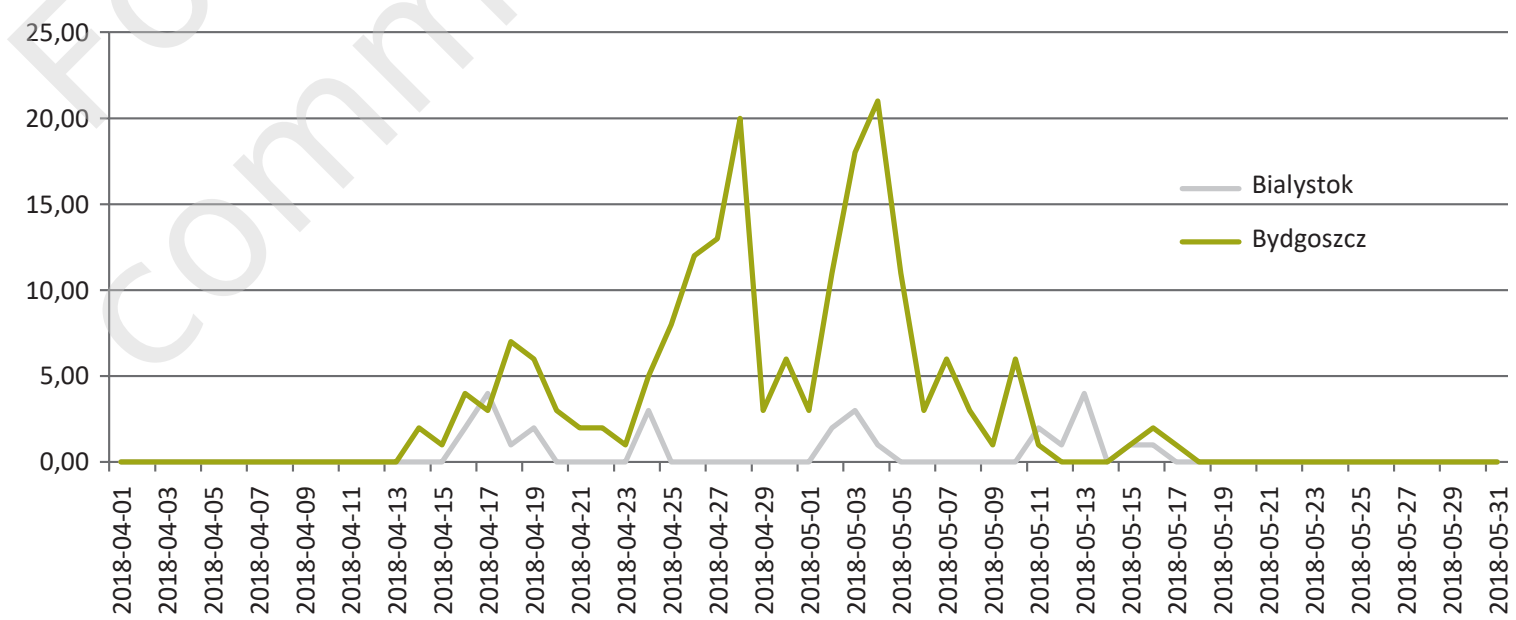

Figure 2. Plane pollen count in Drawsko Pomorskie and Olsztyn.

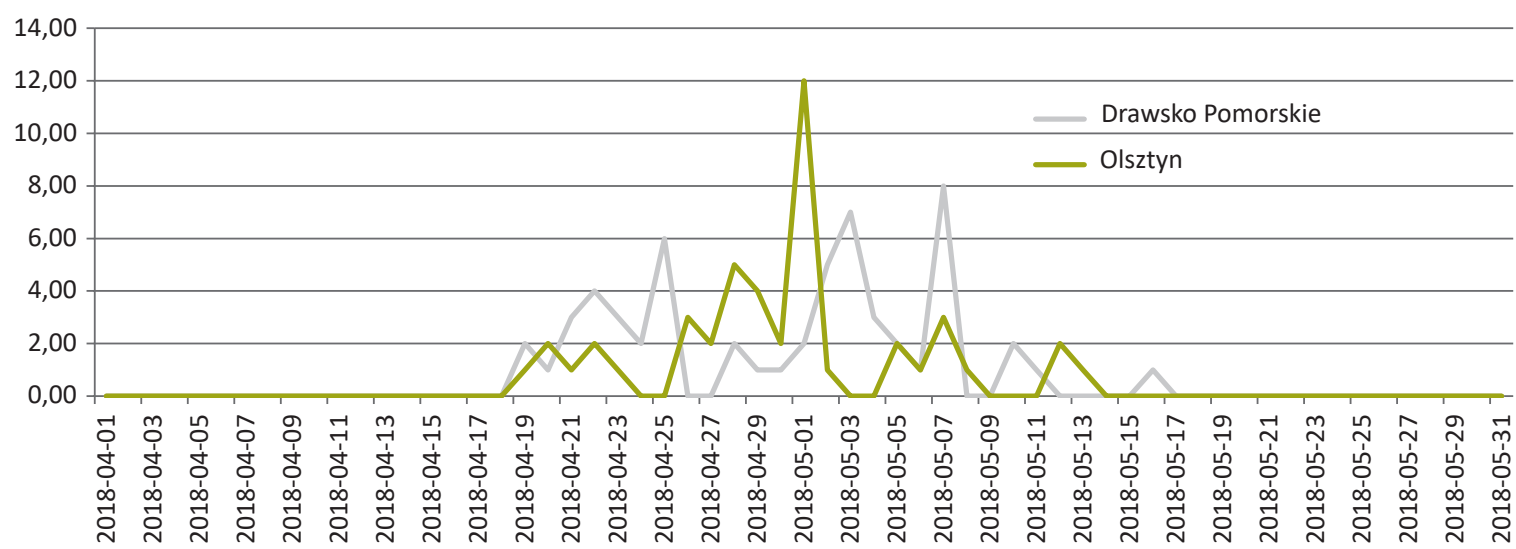


Figure 3. Plane pollen count in Opole and Szczecin.

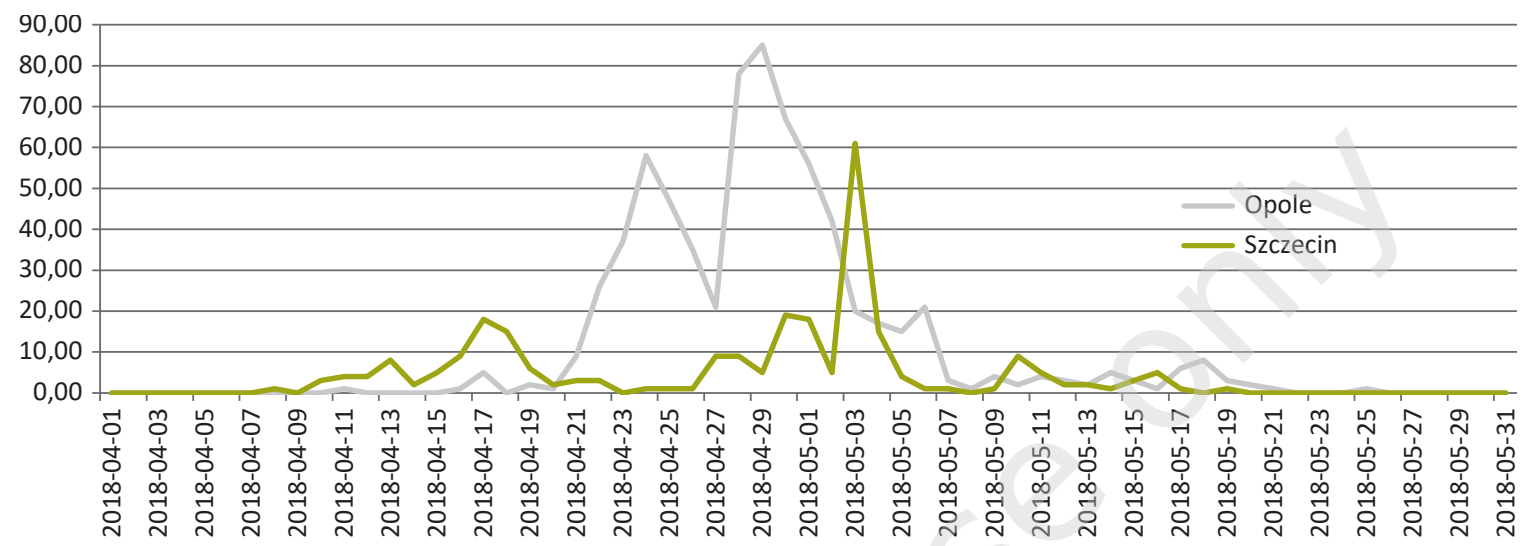

Figure 4. Plane pollen count in Warsaw and Zielona Gora.

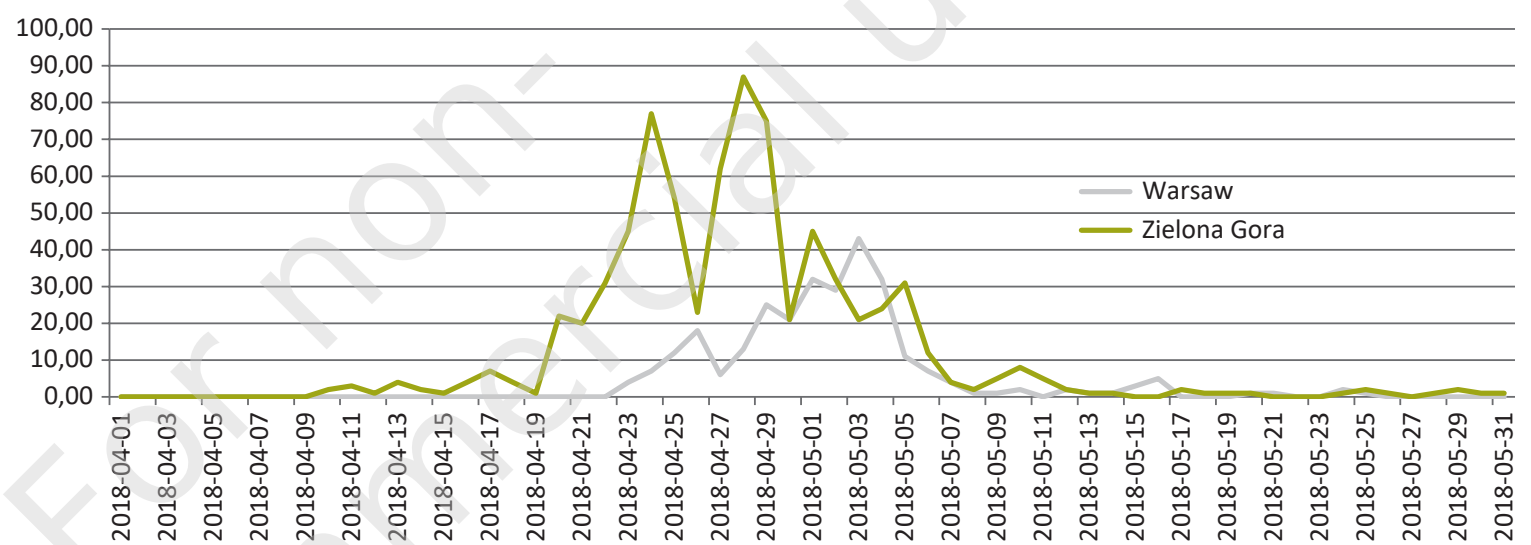

Norris-Hill and Emberlin publish Platanus in London as a highly sensitizing taxon of local importance [4]. Research in Poland confirms that plane pollen can reach high concentrations $[5,6]$.

\section{Conclusions}

In most of the cities, the plane pollen season in 2018 started in the second decade of April.

The highest daily plane pollen concentrations were recorded in Opole and Zielona Gora. The highest risk of pollen allergy associated with the presence of airborne plane pollen was found in Zielona Gora, Opole, Warsaw and Szczecin.

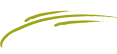

\section{References}

1. Rapiejko P. Alergeny pyłku roślin. Medical Education, Warsaw 2012 (in Polish).

2. Eukasiewicz S. Drzewa i krzewy polecane do obsadzeń ulicznych w miastach. In: Drozdek M (ed). Rośliny do zadań specjalnych. PWSZ Sulechów 2010: 328 (in Polish).
3. Comtois P. Statistical analysis of aerobiological data. In: Mandrioli P, Comtois P, Levizzani V (eds). Methods in Aerobiology. Pitagora Editrice Bologna, Bologna 1998, 3.

4. Norris-Hill J, Emberlin J. Diurnal variation of pollen concentration in the air of north-central London. Grana 1991, 30: 229-234.

5. Puc M. Pytek platanu w powietrzu Szczecina (2009-2010) (in Polish). Alergoprofil 2010, 6(3): 31-32.

6. Puc M, Rapiejko P, Lipiec A et al. Pyłek platana w powietrzu wybranych miast Polski w 2014 r. (in Polish). Alergoprofil 2014, 10(3): 54-57.

ORCID

B. Gałusza - ID - orcid.org/ 0000-0002-9594-5108

A. Lipiec - ID - orcid. org/ 0000-0003-3037-2326

M. Puc - ID - orcid.org/0000-0001-6734-9352

E. Kalinowska - ID - orcid.org/0000-0003-4821-6882

K. Tywoniuk - ID - orcid.org/0000-0002-4610-0002

K. Szczygielski - ID - orcid. org/ 0000-0002-3717-5424

P. Rapiejko - ID - orcid. org/ 0000-0003-3868-0294

\section{Author's contributions:}

Gałusza B: 60\%; and other Authors: $3.63 \%$ each.

Conflict of interests: The authors declare that they have no competing interests.

Financial support: Does not occur.

Ethics: The contents presented in this paper are compatible with the rules the Declaration of Helsinki, EU directives and standardized requirements for medical journals.

Research in Bialystok, Bydgoszzz, Drawsko Pomorskie, Olsztyn, Opole, Warsaw and Zielona Gora funded by Allergen Research Center Ltd. 


\section{Corresponding author:}

\section{Barbara Gałusza, MD}

Department of Otolaryngology with Division of Cranio-Maxillo-Facial Surgery in Military Institute of Medicine 04-141 Warsaw, Szaserów 128

e-mail: bgalusza@wim.mil.pl 